ISLAMOPHOBIA AND THE NOVEL 


\section{LITERATURE NOW}

Matthew Hart, David James, and Rebecca L. Walkowitz, Series Editors

Literature Now offers a distinct vision of late-twentieth- and early-twenty-first-century literary culture. Addressing contemporary literature and the ways we understand its meaning, the series includes books that are comparative and transnational in scope as well as those that focus on national and regional literary cultures.

Caren Irr, Toward the Geopolitical Novel: U.S. Fiction in the Twenty-First Century

Heather Houser, Ecosickness in Contemporary U.S. Fiction: Environment and Affect

Mrinalini Chakravorty, In Stereotype: South Asia in the Global Literary Imaginary

Héctor Hoyos, Beyond Bolaño: The Global Latin American Novel

Rebecca L. Walkowitz, Born Translated: The Contemporary Novel in an Age of World Literature

Carol Jacobs, Sebald's Vision

Sarah Phillips Casteel, Calypso Jews: Jewishness in the Caribbean Literary Imagination

Jeremy Rosen, Minor Characters Have Their Day: Genre and the Contemporary Literary Marketplace

Jesse Matz, Lasting Impressions: The Legacies of Impressionism in Contemporary Culture

Ashley T. Shelden, Unmaking Love: The Contemporary Novel and the Impossibility of Union

Theodore Martin, Contemporary Drift: Genre, Historicism, and the Problem of the Present

Zara Dinnen, The Digital Banal: New Media and American Literature and Culture

Gloria Fisk, Orhan Pamuk and the Good of World Literature 


\section{ISLAMOPHOBIA}

AND THE
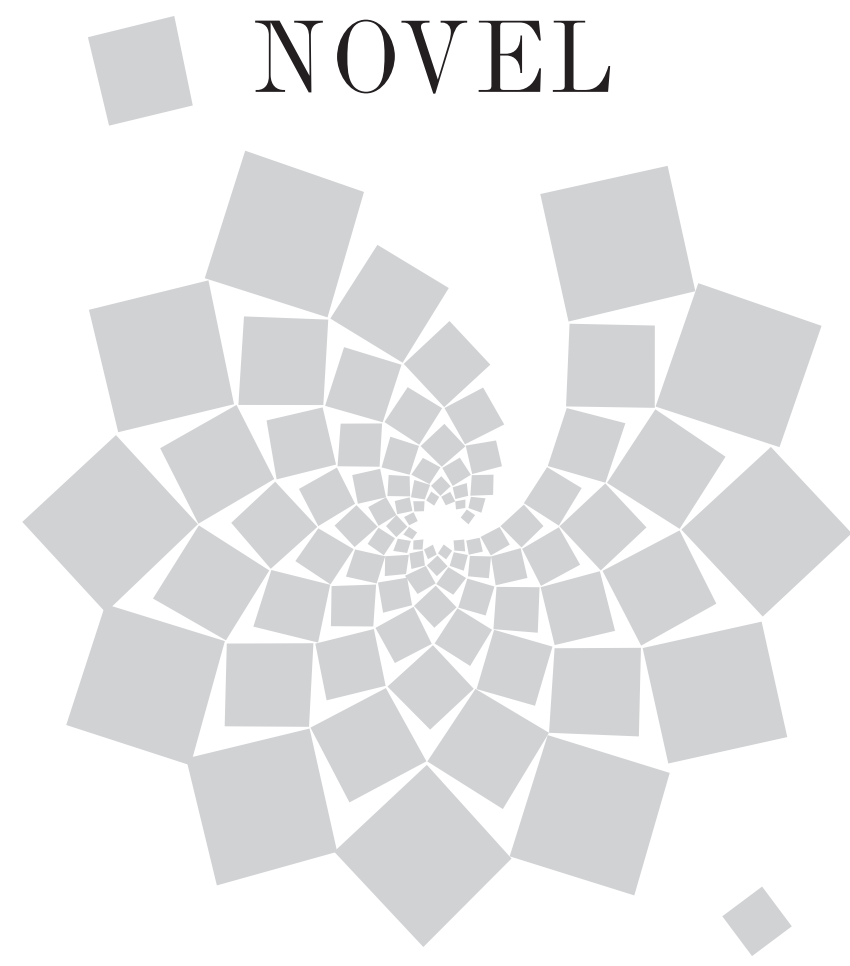

PETER MOREY

Columbia University Press / New York 
Columbia University Press

Publishers Since 1893

New York Chichester, West Sussex

cup.columbia.edu

Copyright (๑) 2018 Columbia University Press

All rights reserved

Library of Congress Cataloging-in-Publication Data

Names: Morey, Peter author.

Title: Islamophobia and the novel / Peter Morey.

Description: New York : Columbia University Press, 2018. | Series: Literature now |

Includes bibliographical references and index.

Identifiers: LCCN 2017055403 | ISBN 9780231177740 (cloth : alk. paper)|

ISBN 9780231541336 (ebook)

Subjects: LCSH: Islamophobia in literature. | Fiction-2oth century-History and criticism. | Fiction-21st century-History and criticism. | Muslims in literature.

Classification: LCC PN3352.I83 M57 2018 | DDC 809.3/938297-dc23

LC record available at https://lccn.loc.gov/2017055403

Columbia University Press books are printed on permanent and durable acid-free paper.

Printed in the United States of America

Cover design and art: Lisa Hamm 
For Bart Moore-Gilbert, scholar, mentor, friend 
